\title{
Preparados, leais e disciplinados: os jornalistas comunistas e a adaptação do modelo de jornalismo americano no Brasil ${ }^{1}$
}

\author{
Afonso de Albuquerque ${ }^{2}$ \\ UFF \\ Marco Antonio Roxo da Silva3 \\ UFF
}

\begin{abstract}
Resumo: O trabalho analisa o papel que os jornalistas ligados ao Partido Comunista do Brasil (PCB) desempenharam no processo de modernização do jornalismo brasileiro entre as décadas de 1950 e 1970. Apresenta evidências de que os comunistas tiveram uma presença significativa nos jornais deste período, inclusive naqueles de linha política conservadora, tanto do ponto de vista quantitativo, quanto qualitativo (em cargos de chefia). Sugere que a tolerância a esta presença por parte dos patrões conservadores obedeceu a razões estratégicas de ambas as partes. Sustenta que, em troca de uma certa autonomia na sala de redação, os jornalistas comunistas ajudaram a construir e garantir redes de disciplina e lealdade que sustentaram as condições para a implementação do novo modelo de jornalismo.
\end{abstract}

Palavras-Chave: Brasil; Jornalismo; Comunismo; Modelo Americano; Objetividade

\footnotetext{
${ }^{1}$ Uma versão prévia deste trabalho foi apresentada no VII Encontro dos Núcleos de Pesquisa em Comunicação - NP de Jornalismo - XXX Encontro Anual da Intercom, Santos (SP), 2007 2 Professor do Programa de Pós-Graduação em Comunicação - UFF 3 Doutor em Comunicação/UFF
} 
"Confessou Luiz Fernando [Ferreira Levy] que preferia jornalistas de esquerda e, particularmente, quem tivesse passado pelo Partido Comunista Brasileiro (PCB): 'Eram os melhores quadros da imprensa, disciplinados, combativos, leais e...conservadores'. Ele não estava longe da verdade."

(Lachini, 2000: 24).

Neste artigo, sustentamos que, entre as décadas de 1950 e 1970, o Partido Comunista Brasileiro (PCB) desempenhou um papel estratégico na adaptação do modelo de jornalismo "independente" americano no Brasil. À primeira vista esta pode parecer uma afirmação estranha, particularmente se considerarmos o fato de que nesta época a Guerra Fria estava no seu ápice. Contudo, acreditamos que a nossa hipótese está respaldada por sólidas evidências. Além de Levy, outros proprietários de jornais conservadores também demonstraram simpatia por jornalistas comunistas. O editorialista do jornal $O$ Estado de São Paulo era comunista, e não escondia o fato do dono do jornal (Müller Filho, 2003: 273-4). Roberto Marinho, o dono das Organizações Globo é citado como tendo se recusado a ceder às pressões de autoridades do regime para demitir alguns esquerdistas de seu jornal, dizendo "dos meus comunistas cuido eu, na minha casa ninguém se mete"4.

Como explicar que os jornalistas comunistas tivessem tanto prestígio entre donos de jornais conservadores naquela época? Sugirimos, aqui, uma relação simbiótica se desenvolveu entre os donos de jornais e os jornalistas comunistas. $\mathrm{Na}$ virada para a década de 1950, transformações expressivas na política e na economia brasileiras proporcionaram aos jornais a oportunidade de se modernizar, com um olho no mercado crescentemente competitivo e o outro nas disputas entre as facções políticas. A modernização incluiu novas instalações, adquiridas em sua maioria com a ajuda de empréstimos a fundo perdido do Banco do Brasil, e um esquema administrativo mais racional (Waisbord, 2000; Ribeiro, 2001). Ela incluiu também a gradual substituição do velho modelo de jornalismo literário e de opinião - inspirado no jornalismo francês, por um modelo mais centrado em fatos (Chalaby, 1996),

\footnotetext{
4 A frase célebre foi uma resposta de Roberto Marinho aos pedidos de Juracy Magalhães, militar e na época, 1965, Ministro da Justiça do governo Castelo Branco, para demitir Franklin de Oliveira, redator de $O$ Globo (Andrade 2003:35).
} 
adaptado dos Estados Unidos. A fim de promover tais mudanças, os jornais precisavam contar com jornalistas preparados e disciplinados, mas os velhos jornalistas não preenchiam esses requisitos, e a cultura jornalística por eles compartilhada era hostil às mudanças pretendidas. Sustentamos, então, que os jornalistas comunistas desempenharam um papel fundamental neste processo, na medida em que forneceram aos jornais profissionais preparados e atuaram como fonte de lealdade e disciplina nas salas de redação.

Naturalmente, os jornalistas do PCB tinham suas próprias razões para tomar parte do processo. Tendo sobrevivido por um longo tempo na ilegalidade, o PCB tinha uma grande experiência nas táticas da clandestinidade política. Uma das mais importantes dessas táticas era a infiltração em instituições culturais estratégicas (tais como os jornais), a fim de obter influência junto à opinião pública. A modernização da imprensa brasileira ofereceu aos comunistas uma boa oportunidade exercer essa influência nas salas de redação. Para ser bem sucedidos, contudo, eles deviam ser tão discretos quanto possível e evitar um viés esquerdista no noticiário. Nos termos do antigo editor de O Estado de São Paulo e da Folha de S. Paulo os comunistas conheciam "as regras do jogo" 5 .

A retórica e os procedimentos práticos e discursivos do modelo americano de jornalismo "independente" forneceram uma boa base para a barganha entre os donos de jornais conservadores e seus empregados comunistas. Ao (formalmente) subscrever o modelo, os donos de jornais podiam reivindicar exercer um serviço público (fornecer informações precisas para seus leitores) e se alinhar com valores tais como liberdade, modernidade e democracia. Os jornalistas comunistas tinham suas próprias e pragmáticas razões para subscrever o modelo. Muitos deles desdenhavam a objetividade como um ideal inacessível e sustentavam que "a liberdade de imprensa é, na verdade, liberdade de empresa”. Contudo, a retórica da objetividade também permitia aos jornalistas reivindicar o exercício de um serviço público e, desta forma, proporcionava a eles alguma autonomia em relação aos seus chefes.

5 O editor é o jornalismo Cláudio Abramo. 
O modelo americano de jornalismo e o comunismo têm sido considerados tão imiscíveis quanto óleo e água. Siebert, Peterson e Schramm (1946) descrevem os modelos americano e comunista soviético como baseados em teorias da imprensa antagônicas: a teoria libertária e a teoria autoritária. No esquema de três modelos, mais sofisticado, proposto por Hallin e Mancini (2004), por sua vez, eles são associados a dois sistemas midiáticos diferentes: o jornalismo americano é apresentado como o exemplo mais puro do sistema midiático liberal, enquanto o modelo do pluralismo polarizado é o único no qual o comunismo pode desempenhar um papel significativo. Por outro lado, os estudos que investigaram a interação entre os dois fatores (por exemplo, Blanchard, 1986) têm sempre enfocado a dimensão do antagonismo entre o comunismo e o modelo americano de jornalismo, em detrimento de outros tipos de relação. A análise do caso brasileiro sugere que o problema pode ser mais complexo do que isto. Na década de 1950, o comunismo e o "American way of life" se apresentavam como dois caminhos alternativos para a modernização do país. Havia muita rivalidade entre eles, naturalmente, mas eles também compartilhavam de traços e perspectivas em comum o suficiente para que pudesse haver algumas alianças táticas entre eles.

$\mathrm{O}$ artigo se divide em quatro partes. A primeira examina dois influentes modelos de análise comparativa dos sistemas midiáticos: o livro Four Theories of the Press, de Fred Siebert, Theodore Peterson e Wilbur Schramm, e o modelo tripartite proposto por Daniel Hallin e Paolo Mancini no livro Comparing Media Systems. Ela sustenta que, não obstante sejam bastante diferentes um do outro, ambos os modelos desenvolvem uma abordagem estática acerca dos fenômenos que estudam, e que um enfoque mais dinâmico é necessário se quisermos entender o modo como os países periféricos lidam com os modelos dos países centrais. Antes que investigar quais modelos eles adotam, trata-se de analisar como eles adaptam esses modelos às suas próprias necessidades.

A segunda seção apresenta algumas breves observações de cunho histórico acerca do PCB, enfocando alguns aspectos que ajudam a entender as razões que levaram os jornalistas comunistas a se juntar aos donos de jornais no seu projeto de modernização da imprensa. 
A terceira seção apresenta e procura explicar algumas evidências acerca da influência exercida pelos jornalistas de esquerda - particularmente aqueles ligados ao PCB - nas salas de redação. Essas evidências têm a ver com o significativo número de membros do PCB (ou outras organizações de esquerda, menos expressivas), a influência exercida pelos jornalistas comunistas na admissão de novos jornalistas, o papel que os editores esquerdistas exerceram, de mediadores políticos entre os donos de jornais e a sala de redação, e a atitude tolerante, e mesmo positiva, que os donos de alguns jornais conservadores mantinham em relação aos jornalistas comunistas. A forte presença de comunistas na redação dos jornais é explicada como conseqüência de uma relação simbiótica entre os jornalistas e donos de jornais: em troca da tolerância destes, os primeiros garantiam qualidade técnica, disciplina e redes de lealdade, que ajudaram a viabilizar o projeto de modernização da imprensa.

A quarta seção, por fim, discute os fatores que levaram ao declínio da influência do PCB nas salas de redação dos jornais ao longo da década de 1970. A exigência de diploma de curso superior em jornalismo proporcionou aos jornais uma oferta de mão de obra especializada em grande escala, sobre a qual o PCB tinha muito menos controle. Além disso, os jornais estavam se tornando organizações mais complexas, de modo que as redes de lealdade estruturadas em torno do PCB. Finalmente, o PCB passou a sofrer a concorrência do Partido dos Trabalhadores (PT) - um partido que adotava uma atitude de confronto em relação ao empresariado - na disputa pela hegemonia no campo da esquerda.

\section{A Análise Comparativa no Jornalismo: Abordagens Estáticas e Dinâmicas}

À primeira vista, a sugestão de que, entre as décadas de 1950 e 1970, os jornalistas comunistas desempenharam um papel estratégico no desenvolvimento de um jornalismo de estilo americano no Brasil pode parecer sem sentido; afinal, neste período os Estados Unidos formavam o principal antagonista do comunismo internacional. Tal perspectiva se reflete também nos estudos comparativos sobre o jornalismo. Embora o antagonismo entre os dois elementos tenha sido obviamente a nota dominante do período, ela não dá conta de todas as dimensões da relação entre eles. A fim de entender como, em uma situação específica, forças supostas como 
antagonistas puderam colaborar, é necessário empregar um modelo de análise mais dinâmico do que aqueles que têm sido comumente utilizados.

Escrito por Fred Siebert, Theodore Peterson e Wilbur Schramm, o livro Four Theories of the Press é geralmente considerado o ancestral dos modernos estudos comparativos sobre o jornalismo. O propósito declarado do livro é correlacionar "as diferentes formas que a imprensa assume em diferentes países" com "as estruturas sociais e políticas dentro das quais ela atua" (1963: 1). Na prática, porém, o que o livro faz é algo muito diferente: ele apresenta um contraste agudo (e bastante parcial) entre o modelo de imprensa americano contemporâneo - apresentado sob o rótulo de "teoria da Responsabilidade Social" - e o modelo Comunista Soviético, à luz dos seus fundamentos teóricos últimos: a teoria Libertária da imprensa, no primeiro caso, e a teoria Autoritária no segundo. De fato, o livro descreve o modelo da Responsabilidade Social como um aperfeiçoamento histórico dos princípios liberais, enquanto a teoria Comunista Soviética é caracterizada como uma formula particularmente perversa da teoria autoritária da imprensa. O livro é, evidentemente, um produto da Guerra Fria, e reflete o clima da cruzada que a imprensa e o governo americanos moveram, ao final da Segunda Grande Guerra, para exportar o modelo americano de jornalismo para todo o mundo (Blanchard, 1986). Como diz Nerone (1995: 25), a dicotomia básica que estrutura o livro é a propriedade privada ou estatal dos meios de comunicação. Para os autores, é apenas na ausência de controle estatal que os meios serão livres para servir ao público; caso contrário, eles servirão para manipulá-lo.

Four Theories of the Press está longe de ser um bom exemplo de uso do método comparativo para a análise do jornalismo. Como Nerone (1995) observou, uma das quatro teorias da imprensa - a Libertária - serve de referencial para a construção de todas as demais: a teoria da Responsabilidade Social é um aperfeiçoamento dela, a teoria Autoritária é o oposto dela, e a teoria do Comunismo Soviético é uma forma piorada da teoria Autoritária. Não obstante seus problemas, ela permaneceu influente durante décadas. Foi apenas na década de 1980 que uma nova geração de estudos trouxe fôlego novo à análise comparativa do jornalismo. $\mathrm{Na}$ sua primeira fase, estes estudos realizaram comparações pontuais entre modelos jornalísticos (ou sistemas midiáticos) em dois ou mais países. Alguns exemplos são a 
comparação entre o jornalismo americano e o italiano por Hallin e Mancini (1984), do jornalismo britânico e alemão por Köcher (1986), e a comparação entre os modelos anglo-americano e francês por Chalaby (1996). Ao contrário de Four Theories, estes estudos têm o mérito de serem baseados em análises empíricas rigorosas, razão pela qual eles representaram um passo decisivo para a consolidação dos estudos comparativos sobre o jornalismo como campo de investigação.

Os estudos comparativos sobre o jornalismo entraram em uma nova fase com a publicação do livro Comparing Media Systems, de Hallin e Mancini, em 2004. O livro propõe um esquema de três modelos para descrever os sistemas midiáticos da América do Norte e da Europa Ocidental: o modelo Liberal (característico dos Estados Unidos, Reino Unido, Irlanda e Canadá); o modelo Democrático Corporativista (característico dos países da Europa central e setentrional) e o modelo Pluralista Polarizado (característico dos países mediterrâneos). Os autores enfatizam que os modelos são tipos ideais e, portanto, países específicos podem combinar características de dois ou mesmo dos três modelos. Assim, por exemplo, os meios britânicos combinariam características do modelo Liberal e do modelo Democrático Corporativista, enquanto o sistema francês teria características dos modelos Democrático Corporativista e Pluralista Polarizado. Os dois autores apresentam um modelo bastante elegante, solidamente baseado nos estudos empíricos disponíveis sobre os sistemas midiáticos da Europa Ocidental e da América do Norte. Os autores defendem que as categorias criadas por eles não devem ser impostas aos estudos realizados acerca de outros países, fora do universo investigado pelos autores, servindo apenas como "um conjunto de modelos em relação aos quais os demais podem ser construídos" (2004: 305). Contudo, não fica muito claro de que modo o esquema dos três autores poderia ser útil para uma análise comparativa em âmbito mundial.

Tomados a partir de um ponto de vista externo, os três modelos parecem ainda mais diferentes entre si do que os autores sugerem. Para além do seu caráter descritivo, de tipo ideal, os modelos Liberal e Democrático Corporativista apresentam também um caráter normativo - o modelo Liberal é o paradigma dominante global e o modelo Democrático Corporativista oferece uma alternativa mais coletivista a ele mas o mesmo não se dá com o modelo Pluralista Polarizado. Ao contrário, a definição 
que os autores apresentam acerca dele enfatizam principalmente suas qualidades negativas (o papel do clientelismo, a pouca importância relativa das normas profissionais, a subordinação dos meios de comunicação à lógica da disputa política, etc). Os autores sugerem que o modelo Liberal é útil para entender as influências externas em outros sistemas midiáticos, associadas ao neoliberalismo e à globalização, o modelo Democrático Corporativista tem traços em comum com alguns sistemas asiáticos e europeus orientais, e o modelo Pluralista Polarizado seria útil para entender os sistemas midiáticos de um grupo bastante diversificado de regiões, que incluiria a África, a América Latina, as repúblicas da antiga União Soviética e a Europa Oriental.

Que o modelo do Pluralismo Polarizado - um modelo definido em termos fundamentalmente negativos - pode ter um valor comparativo para um escopo tão amplo de sistemas midiáticos é algo que merece reflexão: não estaria ele servindo como um sinônimo mais sofisticado de "sistemas midiáticos de países subdesenvolvidos"? Talvez um outro tipo de abordagem seja necessário para lidar com o jornalismo nos países periféricos, que seja capaz de dar conta, de modo mais dinâmico, do modo como estes países se apropriam e reinterpretam os modelos de jornalismo dos países centrais. Na ausência de uma tal abordagem, torna-se muito difícil entender o tipo de aliança que os donos de jornais conservadores e os jornalistas comunistas estabeleceram em torno do modelo de jornalismo americano.

\section{Vivendo nas Sombras: o Partido Comunista Brasileiro}

Fundado em 1922, o Partido Comunista Brasileiro (PCB) existiu durante a maior parte de sua história como um partido político ilegal. Por esta razão, dominar técnicas de ação política clandestina se tornou, para o partido, uma questão de vida ou morte. Desde 1985, o PCB opera legalmente; antes, isso só ocorrera em três breves ocasiões: entre março e julho de 1922, entre janeiro e agosto de 1927 e de outubro de 1945 a maio de 1947.

O período compreendido entre 1945 e 1947 é de particular interesse para o nosso estudo, visto que é imediatamente anterior àquele no qual estamos interessados. Em 1944, o Brasil se juntou aos Aliados na Segunda Grande Guerra, e enviou tropas à Itália para combater as forças do Eixo. Quando a guerra terminou, 
tornou-se óbvio que o regime autoritário do Estado Novo - muito mais próximo aos regimes nazi-fascistas que das democracias ocidentais - estava com seus dias contados. O presidente Getúlio Vargas foi deposto, um sistema multipartidário foi estabelecido e eleições foram agendadas para final de 1945, para eleger o novo presidente e uma Assembléia Constituinte. O PCB tomou parte de ambas as eleições e teve aproximadamente dez por cento dos votos nas duas. Durante o curto período em que funcionou legalmente, o PCB desenvolveu uma ampla rede de comunicações, que incluía oito jornais diários e duas editoras. Muitos intelectuais se juntaram ao partido e, em apenas um ano, o número de seus membros registrados pulou de 5.000 para 180.00o. Em 1947, contudo, como conseqüência da Guerra Fria o partido foi julgado ilegal, acusado de ser o braço brasileiro do Partido Comunista Soviético ${ }^{6}$.

O modo como o partido lidou com a clandestinidade forçada combinou uma estrutura interna autoritária, de inspiração leninista, com uma estratégia política predominantemente moderada, que preferia o caminho das reformas e dos amplos arcos de aliança política à revolução e à luta de classes aberta. Seguindo os princípios leninistas, o PCB adotou uma estrutura fortemente disciplinar: o partido deveria ser uma organização clandestina, coeso ideologicamente e baseado em um sólido respeito pela hierarquia. Tal estrutura tinha, nitidamente, inspiração militar: o ativista era um soldado, o partido, um exército e a Internacional Comunista, o Quartel-General. Do militante comunista, esperava-se que fosse abnegado, dedicado à causa comum e que subordinasse a sua vida pessoal aos interesses da vontade coletiva, tal como representada pelo partido7 ${ }^{7}$ Não obstante fosse estruturado como

\footnotetext{
${ }^{6}$ Com a Guerra Fria e a eleição de Dutra, o partido foi posto na clandestinidade e passou por uma fase de "depuração" de quadros e de idéias para eliminar os desvios à esquerda (troktismo) e à direita (burgueses) num processo chamado de "estalinização". Este período durou aproximadamente dez anos e afetou o papel que o PCB vinha até então tendo no campo cultural através dos seus jornais, que passaram a se submeter às diretrizes do "realismo socialista" Pandolfi, Ibid, p. 127-179 e Dênis de Moraes, 1994, pp. 79-119.

7 A linguagem militarizada, a disciplina e a exigência do cumprimento de tarefas tinham tal rigidez que Luís Carlos Prestes afirmou o seguinte: naqueles tempos (anos 1930) era mais fácil construir o PCB nos quartéis que nas fábricas. (Pandolfi, 1995, 41 e 110). Segundo Reis Filho (1985, p. 119) os partidos comunistas de diversas tendências utilizavam a estratégia da tensão máxima para manter o controle interno, que se manifestava no complexo da dívida: submetido a uma tarefa, o militante tinha de cumpri-la. Se conseguisse, o crédito era da cultura partidária. Senão, ele tinha de se submeter a uma autocrítica e rever os seus erros. A unidade ideológica e de ação entre os militantes era obtida através do centralismo democrático. Segundo, Agildo Barata, o centralismo democrático foi uma máquina de forjar unanimidades. Mas é preciso reconhecer que ele não evitou expurgos e tensões entre a cúpula
} 
um partido revolucionário, o PCB preferiu, durante a maior parte de sua existência a via reformista. De acordo com a perspectiva dominante no partido, não havia, na sociedade brasileira, condições concretas para que fosse dado o passo revolucionário em direção ao socialismo. Antes disto, seria necessário consolidar o capitalismo no Brasil, pré-requisito para a formação do proletariado, a classe verdadeiramente revolucionária. Tal diagnóstico justificava a estratégia do partido de buscar alianças com a burguesia nacionalista do Brasil ${ }^{8}$.

O modelo revolucionário de organização do PCB e o caráter reformista de sua estratégia se combinaram para fazer da "infiltração" em instituições públicas e privadas uma das táticas preferidas do partido9. Ao infiltrar seus membros em instituições culturais, outros partidos políticos e na imprensa, o PCB foi capaz foi capaz de conservar uma influência significativa na política e na cultura, a despeito da ilegalidade. Juntos, a estrutura disciplinar do PCB, a estratégia de alianças com a

partidária e os militantes de base, principalmente operários, que muitas vezes preferiam seguir o espontaneísmo das massas que a orientação do partido (Ferreira, 2002: 279-282). ${ }^{8}$ Isto fazia parte da visão dualista que o PCB tinha sobre a economia brasileira. Era preciso eliminar os resquícios feudais mantidos no campo pelo arranjo de interesses entre "imperialismo" e a burguesia agro-exportadora brasileira. A estratégia para superá-lo era uma política de alianças com setores nacionalistas para fomentar a industrialização e para consolidar a "etapa" liberal-democrática, acumular forças e aí fazer a sociedade evoluir até o socialismo. A tática para isso variava conforme a conjuntura: nos anos 1930, para conter o fascismo o Partido seguiu as deliberações da III ${ }^{\mathrm{a}}$ Internacional e defendeu uma política de aliança pluriclassista e de reformas graduais. Após a cassação e a radicalização em 1947, predominou da tese da ruptura revolucionária e a formação de uma frente popular de massas para consolidar a fase democrática. A via pacífica do reformismo começou a predominar com a publicação do Manifesto de 1958, expondo as novas diretrizes do PCB e foi facilitada pelo processe de desestalinização da União Soviética. Os grupos que defendiam a via revolucionária abandonaram o Partido e fundaram, em 1962, o Partido Comunista do Brasil. Ver Dória (1998, p. 213-214) e Pandolfi, Ibid. p 200.

9 O termo "infiltração" indicava inicialmente o trabalho dos militantes comunistas nas portas das fábricas e oficinas para cooptar novos quadros para o Partido. Nos anos 1960, ele passou incorporar a inserção de militantes em outros organismos da sociedade civil, como a Indústria Cultural. Neste caso, a "infiltração" implicou no abandono das formas artesanais de arte como forma de educar as massas. As trajetórias de dois militantes são ilustrativas desse processo. Para teatrólogo Gianfrancesco Guarnieri, as novelas da Rede Globo realizavam o projeto do CPC da UNE de fazer uma arte para o povo. O diretor-executivo de jornalismo do SBT, Albino de Castro Filho, afirmou que o noticiário mundo cão do programa Aqui e Agora era gramsciano, enquanto as novelas da Rede Globo eram "lukacsianas, puro realismo crítico narrativo". Segundo Celso Frederico, a cooptação dos militantes pela indústria do entretenimento ocorreu porque até a 1964 a esquerda agia com desenvoltura e sem concorrência no campo cultural. Depois, capitalizados pelo Estado, os monopólios privados de comunicação puderam atrair para si parte dos artistas e jornalistas formados no Partido (Frederico, 1998: 295). 
burguesia nacional e as táticas de infiltração usadas pelo partido ajudam a explicar como os jornalistas comunistas vieram a desempenhar um papel central na adaptação do modelo americano de jornalismo para o Brasil.

\section{Um Casamento de Conveniência}

O relato padrão sobre a modernização do jornalismo brasileiro conta que, no início da década de 1950, um pequeno grupo de jornalistas do jornal Diário Carioca Danton Jobim, Pompeu de Souza e Luis Paulistano são comumente citados como os pais fundadores do jornalismo brasileiro moderno - "trouxeram" dos Estados Unidos um conjunto de valores - estruturados em torno da "objetividade jornalística" - e práticas - como por exemplo, o uso do lead na abertura das matérias - que, logo, se difundiram entre os jornalistas brasileiros (Amaral, 1996). Embora raramente contestada, esta narrativa é obviamente insuficiente: ela não apresenta quaisquer pistas que ajudem a explicar de que modo o modelo se difundiu no jornalismo brasileiro. Dado que os jornalistas brasileiros não compartilhavam dos valores implícitos do modelo de jornalismo independente (Waisbord, 2000; Albuquerque, 2005), é razoável supor que alguma força disciplinar foi necessária para permitir que a implantação do novo modelo pudesse obter sucesso. Neste artigo, defendemos que os jornalistas ligados ao PCB desempenharam um papel importante nesse processo disciplinar, e que eles tinham razões políticas para fazer isso. As evidências disso serão apresentadas nos parágrafos seguintes.

Para começar, os membros do PCB compunham uma parcela expressiva dos jornalistas brasileiros durante o período em análise. De uma amostra de 55 jornalistas, ativos nas décadas de 1960 e 1970, entrevistados por Abreu (2003:42), 43\% declararam que haviam participado de partidos ou movimentos de esquerda, e destes, 61\% haviam sido membros do PCB. Os jornalistas que foram membros do PCB respondem por cerca de um quarto da amostra, portanto. Os comunistas também obtiveram influência entre os editores e secretários de redação: Augusto Nunes, Élio Gaspari e Roberto Müller são apenas alguns exemplos de uma longa lista de jornalistas influentes afiliados ao PCB. É geralmente aceito que os jornalistas tendem a ser mais esquerdistas que os jornais para os quais eles trabalham (Hallin e Mancini, 2004), mas o nosso caso fornece a evidência de algo além disso: a forte 
presença, nas salas de redação, de uma organização política. Isto sugere que o PCB pôs em prática uma estratégia bem sucedida de infiltração nos jornais.

Com efeito, ser membro do PCB - ou, em menor grau, de outras organizações políticas de esquerda - parece ter servido para muitas pessoas como um atalho para o jornalismo. Um companheiro de partido levou Etevaldo Dias para trabalhar em $O$ Jornal, onde ele ficou por sete meses. Mais tarde, ele se transferiu para O Globo (Conti: 1999: 127). Carlos Alberto de Oliveira era um estudante de direito, membro do PCB e integrante do movimento estudantil em Salvador durante o regime militar. Para escapar da prisão, ele fugiu para o Rio de Janeiro, e foi trabalhar no jornal sensacionalista Luta Democrática por indicação de colegas comunistas. Há muitas histórias semelhantes, que sugerem que a contratação de comunistas pelos jornais obedecia a um plano sistemático. Isto não escapava aos donos de jornais, mas, ao que tudo indica, não lhes trazia preocupação. O caso de João Sant'Anna o ilustra bem Jornalista e militante da Dissidência Comunista (uma dissidência do PCB), ele passou um ano e meio preso como subversivo. Quando foi libertado, procurou emprego em $O$ Globo. Ele foi admitido, com um bom salário, mas sem um contrato formal, pois, como lhe foi explicado, o jornal "tinha subversivos demais" e era preciso evitar suspeitas do Serviço Nacional de Informações (SNI). Quando a Lei de Anistia foi aprovada, quatro anos mais tarde, O Globo formalizou a contratação de Sant'Anna (Smith, 1997: 65).

Como explicar a tolerância que jornais conservadores demonstraram em relação à contratação de membros de organizações de esquerda? Talvez solidariedade humana possa ter sido um fator, mas ela obviamente não basta para explicar o comportamento de organizações complexas e capitalistas como os jornais. Devemos, portanto, admitir que os jornais obtiveram algum tipo de vantagem institucional na contratação de tais jornalistas. Sustentamos aqui que, ao admitir membros de organizações de esquerda - especialmente do PCB - os jornais obtiveram três tipos de benefícios: jornalistas preparados, disciplina no trabalho e lealdade política.

Há duas principais razões pelas quais o PCB provinha profissionais preparados para os jornais. Em primeiro lugar, o PCB contava com uma considerável infra-estrutura de comunicações, que incluía muitos jornais. É bem possível então 
que a imprensa do PCB funcionasse como uma escola para muitos jornalistas ${ }^{10}$. Em segundo lugar, visto que o PCB escolhera a arena cultural como seu principal campo de batalha, ele dedicou um esforço considerável na preparação dos seus ativistas. O caso de Ancelmo Góis é ilustrativo, a este respeito. Nascido em uma família pobre do Nordeste, ele recebeu uma educação deficiente. Adolescente, tornou-se membro do PCB e ativista do movimento estudantil em Aracaju. Perseguido por subversão, fugiu para o Rio de Janeiro, de onde o PCB o enviou para Moscou, para cursar A Escola Preparatória para Jovens Ativistas. Tendo retornado ao país, ele concluiu o curso universitário de jornalismo, com o apoio do partido ${ }^{11}$.

A disciplina é um valor profundamente enraizado na história do movimento comunista. No Manifesto do Partido Comunista, publicado originalmente em 1848, Marx e Engels sustentam que, ao submeter os trabalhadores das indústrias a um rígido sistema disciplinar, os capitalistas estão, de fato, proporcionando a eles uma organização de tipo militar, e lhes dando os instrumentos que eles um dia utilizarão para combater a ordem capitalista. Lênin também atribuiu grande valor à disciplina. Para ele, o Partido Comunista deveria ser a vanguarda do proletariado, encarregada de fornecer ao movimento a disciplina e a coordenação necessárias ${ }^{12}$. Não é surpreendente, então, que os jornalistas membros do PCB tivessem suas próprias razões para favorecer a disciplina nas salas de redação ${ }^{13}$. Por outro lado, dada a

\footnotetext{
${ }^{10}$ Durante o seu curto período de vida legal entre 1946 e 1947, o PCB criou uma ampla rede de comunicação através dos seus jornais. Esta rede foi potencializada com a inserção de intelectuais, entre eles jornalistas, escritores e artistas filiados ou afetivamente ligados ao Partido. O ingresso destes quadros favoreceu um determinado "nível de qualidade jornalística”, permitindo que a imprensa comunista fosse vista como uma verdadeira escola de jornalismo, com o aprendizado no interior dos jornais do partido facilitando o trânsito de jornalistas para a grande imprensa. Ver Rubim, 1998: 317.

${ }^{11}$ Ancelmo Góes estudou jornalismo na Faculdade Hélio Alonso e o seu primeiro emprego foi em uma das revistas técnicas da Editora Abril, Máquinas e Metais, cujo diretor era David de Morais, presidente do Sindicato dos Jornalistas Profissionais de São Paulo entre 1978 e 1981. Ver Conti, 1999:400.

${ }^{12} \mathrm{O}$ modelo leninista de partido exigia dos militantes comunistas um forte espírito de abnegação pessoal. Eles deviam servir de modelo às pessoas comuns, mostrando sua devoção à causa, disciplina ao partido e correção no plano familiar, moral e profissional. No caso do $\mathrm{PCB}$, as atitudes exigidas de um autêntico bolchevista tornaram-se para os militantes comunistas modelos exemplares de todas as suas atividades no plano partidário e privado. A vida pessoal regrada e discreta era fundamental para não despertar suspeitas sobre a militância clandestina (Ferreira, 2002, pp. 71-88).

${ }_{13}$ Além de favorecer a disciplina, este ethos não era refratário a algumas noções jornalísticas que tinham como referente o modelo norte-americano de jornalismo. Segundo Roberto
} 
centralidade da arena política para o PCB, sua estratégia aliancista e sua situação de clandestinidade, não havia qualquer interesse em converter esta disciplina em uma arma subversiva contra os donos dos jornais, ao menos em um curto prazo ${ }^{14}$.

Assim, para os jornalistas comunistas não havia qualquer contradição entre ajudar a consolidar um modelo de jornalismo associado aos Estados Unidos - o líder mundial da campanha anticomunista, que incluiu dentre outras coisas uma "cruzada pela imprensa livre” (Blanchard, 1986) e seus próprios valores políticos. Eles costumavam usar a retórica do jornalismo "independente", mas o faziam enquanto linguagem técnica do jornalismo, antes que como um objeto de crença.

Paradoxalmente, é possível que a aceitação dos jornalistas comunistas a uma ordem disciplinar na qual eles não acreditavam tenha sido tornado mais fácil pela percepção da distância radical entre os seus interesses e os dos donos de jornais. Cláudio Abramo, que se auto-definia como marxista, embora não membro do PCB, ex-editor-chefe de O Estado de São Paulo e da Folha de S. Paulo apresenta um argumento interessante neste sentido. Segundo ele, o jornalismo não tinha uma ética especial: tratava-se antes de um artesanato que de uma profissão. Como qualquer outro trabalhador, os jornalistas deveriam fazer o melhor no seu emprego. Eles deveriam contar os fatos de modo tão completo e preciso quanto possível, e interpretá-los com base em seus próprios pontos de vista, mantendo, contudo uma mente aberta (1993: 110). Tais valores pertencem ao senso comum, e valem para os jornalistas tanto quanto para todos as demais pessoas. Assim, de acordo com Abramo, não são os seus valores que distinguem os jornalistas das demais pessoas,

Muller Filho (2003, p. 272), o seu espírito isenção e apelo à coisa pública foram herdados de sua militância no PCB.

14 No VI Congresso em 1967, o PCB reafirmou o reformismo e política de alianças para combater a ditadura. Esta (re)leitura derivou do modo como o Partido interpretou o golpe de 1964, fruto de um "desvio à esquerda" do bloco de forças democráticas e nacionalistas no qual estava inserido. A política de alianças implicava na atração de setores da burguesia nacional, entre eles o patronato dos jornais, para a oposição institucional liderada no plano parlamentar pelo Movimento Democrático Brasileiro, MDB, e na sociedade civil por entidades como a Ordem dos Advogados do Brasil, Associação Brasileira de Imprensa e Conselho Nacional dos Bispos do Brasil. O PCB foi acusado por grupos vinculados à luta armada de ser "direitista, etapista, reformista e conciliador". Este tipo de conflito no campo da esquerda terá os seus reflexos no jornalismo anos 1980 quando o Partido dos Trabalhadores passou a disputar a hegemonia com os comunistas construindo uma frente de massas para se opor a frente pluriclassista defendida pelos comunistas. Ver Frederico, 1998: 279-284 e Sérgio de Moraes, 2006:59 e 88. 
mas o tipo de compromisso que eles têm com eles: os jornalistas desempenham um serviço público e, por isso, têm mais responsabilidades do que as demais pessoas. Por outro lado, os jornalistas comunistas sabiam que a sua liberdade era limitada pela posição ideológica dos jornais nos quais eles trabalhavam: os jornais são organizações hierárquicas, e numa sociedade capitalista os patrões estão logicamente no topo. Assim, gostando ou não, os jornalistas deveriam conhecer bem a sua posição na hierarquia e agir de acordo com ela. Esta é uma forma de censura, claro, mas tais eram as regras do jogo ${ }^{15}$. Os donos raramente tomavam parte diretamente na censura, afinal, não é exatamente por isso que eles têm uma organização burocrática a seu serviço? Abramo usa o seu próprio exemplo como editor-chefe para ilustrar isso: "Eu devo ter suprimido milhares de matérias ao longo de trinta anos. Não podia publicar, porque era contra a linha do jornal" (1993: 118).

Este tipo de pragmatismo comunista não era uma idiossincrasia de Cláudio Abramo. Os membros do PCB tinham ainda mais motivos para subscrevê-lo. Do seu ponto de vista, obedecer à hierarquia dos jornais não era simplesmente uma questão de manter o próprio emprego, mas de responsabilidade com o partido clandestino ao qual pertenciam. Isto se tornou particularmente verdadeiro durante o regime militar, quando atitudes descuidadas de apenas um indivíduo podiam ser interpretadas como provocações pelas autoridades, e resultar em retaliações desastrosas para os jornalistas como um todo e, mesmo, para o jornal do jornalista "ofensor" ${ }^{16}$. Esta é, provavelmente, a razão pela qual os jornalistas comunistas tinham uma boa reputação entre os donos de jornais. Nas palavras de Evandro Carlos de Andrade,

\footnotetext{
15 Para Cláudio Abramo (1993:169) os jornalistas membros do Partido Comunista eram os profissionais mais fáceis de lidar no ambiente das redações. São os mais disciplinados e os mais racionais na ação diária e no trabalho. Faz-se um trato e eles cumprem, não brincam em serviço e não procuram forçar nada. Em todos esses anos nunca encontrei dificuldades com membros do PC, cujos militantes são de um comportamento exemplar do ponto de vista do jornal. Para o meu gosto acho até meio besta, mas para um jornal capitalista seu comportamento é exemplar.

${ }^{16}$ Um exemplo foi o Mino Carta. Carta saiu da Veja em 1975 por se recusar a censurar um artigo escrito pelo dramaturgo Plínio Marcos, colaborador da revista, por ordem de Victor Civita, dono da Editora Abril. Para Civita, o artigo continha grave conteúdo político e poderia causar sérios danos à empresa. Com medo das represálias dos militares, Civita censurou o artigo e demitiu Plínio Marcos. Para Carta, a demissão significou a ruptura de pacto que ele tinha com Civita deste não intervir no conteúdo do material escrito pelos colaboradores. Não concordando a censura patronal, Carta alegou que por uma questão de princípios não poderia continuar na revista e pediu demissão. Silva, 2003: 63 .
} 
editor-chefe de O Globo, "comunista sabe o que pode fazer, não se mete a besta, é profissional, faz aquilo só e sabe que não pode ir além” (Andrade: 2003: 35) ${ }^{17}$.

Acreditar que se estava sob censura provavelmente servia como um poderoso álibi moral para os jornalistas comunistas, o que lhes permitia trabalhar para jornais conservadores sem se sentirem culpados. Afinal, todos estavam subordinados a mais alguém. Numa estrutura capitalista, não se supunha que eles tomassem as decisões finais, embora em certas ocasiões eles poderiam fazer uma diferença para melhor. Tal crença provavelmente ajuda a explicar porque os jornalistas brasileiros foram tão aquiescentes com a censura durante o regime militar, como sugere Smith (1997): de uma perspectiva comunista, o exercício da auto-censura era uma conseqüência óbvia de se trabalhar em uma organização capitalista. A ditadura militar acrescentou um elemento de medo a isto, mas não mudou a natureza essencial do problema ${ }^{18}$.

A hierarquia e a disciplina dos jornais eram autoritárias, naturalmente, mas isto estava longe de ser um problema insuperável para os jornalistas que eram membros do PCB. Para começar, como membros de um partido comunista, eles valorizavam a subordinação dos indivíduos aos interesses coletivos, e tinham muita experiência em lidar com organizações autoritárias e hierárquicas ${ }^{19}$. Além disso, a

\footnotetext{
${ }^{17}$ Segundo Almeida e Weiss (1998: 357-358) os donos de jornais tinham um elevado grau de confiança nos jornalistas pertencentes ao PCB. Eles representavam um antídoto às surpresas que os "porralocas" (jornalistas simpatizantes de outras correntes de esquerda) poderiam aprontar numa redação.

${ }_{18}$ Alguns trabalhos procuram mostrar como a morte de Wladimir Herzog significou um ponto de inflexão neste tipo de padrão complacente dos jornalistas com a censura. Mas, incorporação dos jornalistas as grandes redes de luta por direitos humanos e sociais que compuseram parte da resistência à ditadura não se deu unicamente por "dentro" dos jornais. Ela também ganhou escopo através do engajamento sindical e isto foi facilitado pelo fato das entidades de classe dos jornalistas serem dominadas por lideranças de esquerda, como Audálio Dantas (1975) e David de Morais (1978) em São Paulo, Carlos Alberto Caó de Oliveira (1979), David Fitchel (1981) e José Carlos Monteiro (1984) no Rio de Janeiro e Audálio Dantas na Federação Nacional dos Jornalistas em 1984. Ver Sérgio de Morais, 2006: 59-85 e Silva, 2003: 88-89.

19 A estrutura centralizada e o mecanismo do centralismo democrático sufocavam os impulsos individuais subordinando-o à orientação coletiva e as diretrizes impostas pela cúpula partidária. Este quadro tem ressonância com a estrutura organizacional das redações onde a autonomia individual do jornalista tinha de se subordinar a hierarquia das redações e esta à orientação da cúpula da empresa proprietária do jornal. É importante afirmar que o modelo leninista de partido acompanhou toda a trajetória de vida do PCB. Carlos Nelson Coutinho em 1979 e o Núcleo Comunista do Rio de Janeiro em 1983 é que lançaram manifestos afirmando a necessidade dos comunistas reconhecerem a democracia e as liberdades individuais como
} 
disciplina relativamente impessoal exercida nas salas de redação era, por certo, muito sofisticada, se comparada ao velho padrão de subordinação direta aos interesses dos donos de jornais que, por muito tempo, tinha sido a regra para os jornalistas brasileiros. Alguns dos antigos donos de jornais se notabilizaram por serem particularmente despóticos. Assis Chateaubriand - o dono do grupo midiático Diários Associados, e considerado uma das pessoas mais poderosas do Brasil entre as décadas de 1930 e 1950 - foi famoso por humilhar os jornalistas que trabalhavam em seus jornais (Morais, 1994). Comparada a isto, a rígida ordem hierárquica das modernas salas de redação se constituía como um evidente progresso. Havia regras claras a seguir e, não obstante a autonomia dos jornalistas individuais permanecesse ainda um tanto restrita, a autonomia dos jornalistas como grupo se tornava muito maior: as decisões sobre as notícias eram tomadas principalmente entre os próprios jornalistas nas salas de redação, apesar de os donos terem a última palavra ${ }^{20}$.

Paralelamente à disciplina, a lealdade era um princípio bastante valorizado entre os membros do PCB. Enquanto a disciplina diz respeito à relação baseada em regras impessoais, o que implica na subordinação dos indivíduos a uma determinada ordem, racional e utilitária, a lealdade é um laço entre pessoas, e envolve valores tais como honra, respeito e generosidade. Esta lógica não se baseia em critérios de eficiência, mas no tipo de relação social que Marcel Mauss (s.d) denomina "reciprocidade". Como os demais partidos comunistas, o PCB enfatizava a lealdade de seus membros em relação aos seus colegas de partido (os “camaradas"), ao partido em si mesmo e à classe operária como um todo. Se a disciplina diz respeito ao que os jornalistas ofereciam aos donos de jornais, a lealdade aponta para o modo como eles faziam isso. Sustentamos que as redes de lealdade entre os comunistas foram recorrentemente usadas como meio para cooptar jornalistas para a ordem

\footnotetext{
valores universais. Mas, estes apelos esbarraram, segundo estes manifestos, numa concepção anacrônica de organização partidária Ver Pandolfi, ibid, 216 e 218.

${ }^{20}$ Segundo Kucinski (1998:27) nos sistemas jornalísticos, as hierarquias também são formadas por jornalistas, editores, secretários de redação, subeditores, de modo que o controle social da informação e os mecanismos de filtragem ou supressão de correntes de opinião dificilmente podem ser operados sem a cooperação dos próprios jornalistas. Daí a importância da cultura profissional e da ideologia do jornalista para que ele mantivesse um mínimo de autonomia profissional. O problema é que a tradição autoritária existente nas redações inviabilizava a formação de uma consciência coletiva entre os jornalistas brasileiros, de modo a limitar severamente as intromissões do patronato no processo de produção noticiosa.
} 
disciplinar. Isto teria acontecido principalmente em duas circunstâncias: a admissão de novos jornalistas e a mediação, exercida pelos jornalistas graduados, entre os donos de jornais e os jornalistas na sala de redação.

A admissão de membros do PCB (ou outro grupos de esquerda) foi um elemento crucial para a formação de redes de lealdade nos jornais. Ao admitir pessoas cujas idéias eram diferentes, e mesmo antagônicas em relação à posição dos seus jornais, os donos podiam não apenas dizer que tinham a mente aberta, como também cultivar com os jornalistas uma relação de tipo paternalista, esperando respeito e lealdade em troca. Este padrão personalista de relacionamento é evidenciado pelos depoimentos de muitos jornalistas. Cláudio Abramo, por exemplo, declarou gostar de seu chefe, Júlio Mesquita (ou Dr. Julinho, como o chamava) como um pai, não obstante o considerasse esnobe e reacionário. Do mesmo modo, tornouse comum referir-se aos comunistas de $O$ Globo como "os comunistas do Dr. Roberto". Note-se que, em ambos os casos, o tratamento dado aos patrões combina características de hierarquia ("doutor" é um tratamento usual para pessoas poderosas no Brasil) e informalidade (o uso de prenomes e/ou diminutivos), o que reforça a impressão de paternalismo.

Os jornalistas comunistas compartilhavam também uma outra concepção de solidariedade, mais próxima do sentimento de pertencer a um grupo de pares (pessoas que defendiam a mesma causa ou eram membros do mesmo partido). Essas redes de solidariedade estiveram presentes antes do regime militar, mas foram reforçadas neste período como resultado da perseguição movida por este contra os comunistas, muitos dos quais perderam seus empregos ou foram presos sob a acusação de subversão (Markun: 2005). Dado que a imprensa se tornou uma das únicas alternativas de emprego para os comunistas, os jornalistas de esquerda tendiam a perceber que seu comportamento pessoal era fundamental para manter essas opções abertas ${ }^{21}$.

\footnotetext{
${ }^{21}$ Segundo Almeida e Weiss (Ibid: 357-358), os jornalistas comunistas formavam redes de proteção recíproca para dar emprego a outros militantes e simpatizantes. Para eles, a presença dessa rede de solidariedade entre comunistas era tolerada pelos donos de jornais por dois motivos. De um lado, em função do elevado senso de profissionalismo e da disciplina que eles impunham à produção jornalística. De outro, porque permitiam aos empregadores gozarem do status de liberais por não discriminarem ninguém por motivos ideológicos. Para o
} 
O papel de mediação entre os patrões e a sala de redação, exercido pelos jornalistas mais experientes desempenhava um papel essencial no processo de cooptação dessas redes de lealdade em benefício da disciplina dos jornais. Este processo é descrito por Abramo nos seguintes termos:

"O jornal era um produto pensado e saía de um projeto global maior, feito de acordo com o dono do jornal. Tinha-se uma estratégia e uma tática, como em tudo na vida. Assim, posso ter uma linha conservadora ou radical de esquerda, mas o jornal tem que ter um programa, um projeto. Esse projeto pode estar impresso, escrito, falado, entendido ou subentendido entre o chefe da redação, o dono do jornal e o pessoal da redação. O importante é que a redação entenda o que se quer fazer" (1988: 167).

A retórica e as práticas adaptadas do modelo americano de jornalismo forneciam um sistema comum de referências que facilitava a comunicação entre os donos de jornais, os editores e os demais jornalistas. Isto não significa que estes o adotassem como o seu próprio modelo, contudo. Muitos jornalistas brasileiros comumente se referiam à objetividade com desdém, como um mito ou mesmo uma mentira, mas ao mesmo tempo defendiam que os jornalistas deviam fazer um uso formal das regras da objetividade (tais como ouvir os dois lados ou adotar um estilo de escrita distanciado), visto que estes eram os valores oficiais da maioria dos jornais brasileiros (Rossi, 1980; Costa, 1991). Assim, eles aderiam ao modelo não porque acreditasse nele, mas simplesmente por conta do seu valor prático:de um lado, ele permitia aos jornalistas com perspectivas e interesses muito diferentes trabalhar juntos, de outro, a objetividade fornecia um álibi para o exercício político do jornalismo, uma vez que o apelo aos fatos podia ser ao mesmo tempo um argumento de defesa e de legitimação de sua produção noticiosa.

A referência ao modelo americano proporcionava vantagens diferentes para os donos dos jornais, os editores e os jornalistas da sala de redação. Os donos de jornal podiam se valer deles para destacar o compromisso dos seus jornais com valores tais como a democracia e a modernidade (Waisbord, 2000; Albuquerque, 2005). Para os jornalistas das salas de redação, a retórica e as práticas inspiradas no jornalismo americano serviam de linguagem técnica comum, com base na qual eles

PCB, a formação dessas redes era vital para os comunistas ocuparem postos na cúpula dos jornais. 
podiam se reconhecer como membros de um grupo de trabalhadores especializados, distintos dos jornalistas precedentes, freqüentemente caracterizados como subliteratos e irresponsáveis (Ribeiro, 2000). Para alguns jornalistas novatos, o aprendizado dessas regras ganhava ares de iniciação em um conhecimento esotérico. José Maria Mayrink, por exemplo, relata que seu chefe no Correio de Minas, Dídimo Paiva "destroçava quem tropeçasse na estrutura do texto ideal - claro para ele, inatingível para nós" (2002: 25). Por fim, os editores e os jornalistas mais experientes, pioneiros do novo estilo de jornalismo, podiam reivindicar o status de autoridades últimas neste campo. Para uma geração inteira de jornalistas, eles foram considerados não apenas como superiores hierárquicos, mas como professores da técnica jornalística e líderes do movimento de modernização do jornalismo brasileiro.

O pioneirismo ajuda a explicar o estilo carismático de liderança exercida pelos editores brasileiros entre as décadas de 1950 e 1970, mas não explica tudo. Na ausência de uma cultura profissional compartilhada, e dada a enorme distância ideológica entre os donos de jornais conservadores e a massa dos jornalistas que trabalhavam para eles, os editores e jornalistas mais experientes tinham que agir como mediadores políticos entre eles. Na ausência de algum apoio (mesmo implícito) do PCB e de outras organizações de esquerda das quais os jornalistas participavam, é pouco provável que eles tivessem logrado sucesso. Embora não apoiasse ativamente o modelo de jornalismo americano, o PCB ajudou a fornecer às salas de redação a disciplina e a estabilidade política necessárias para pô-lo em prática (ainda que em sua forma adaptada).

Em suma, entre os donos de jornais conservadores e os jornalistas comunistas se estabeleceu um casamento de conveniência, não um baseado em amor verdadeiro. Os proprietários obtiveram do PCB a disciplina e as redes de lealdade necessárias para manter as suas salas de redação estáveis o bastante para permitir a modernização dos seus jornais. Em troca, eles consentiram que os comunistas fizessem dos seus jornais sua área de influência, ainda que dentro de limites estritos.

\section{Crise e Divórcio}

Os casamentos de conveniências duram apenas enquanto são convenientes para ambas as partes. No final da década de 1970, contudo, os donos de jornal não 
tinham mais qualquer interesse em manter o acordo com os jornalistas comunistas. Os jornais haviam mudado e eles não precisavam dos comunistas para obter jornalistas preparados, disciplina e redes de lealdade. Do ponto de vista dos proprietários, os custos de se tolerar a influência comunista em seus jornais progressivamente ultrapassou os benefícios que isso gerava.

O papel do PCB como provedor de jornalistas preparados para os jornais conservadores declinou progressivamente ao longo da década de 1970 e é razoável supor que o decreto-lei $\mathrm{n}^{\circ}$ 972, de 17 de outubro de 1969, que regulamentou a profissão de jornalista, tenha tido algo a ver com isso. O decreto foi outorgado pela Junta Militar, composta pelos ministros do Exército, Marinha de Guerra e Aeronáutica Militar, que governou o país durante dois meses em 1969, em um momento em que o Congresso Nacional se encontrava fechado pela ditadura. Entre outras coisas, o decreto-lei estabelecia que o curso superior em Jornalismo seria um pré-requisito para o exercício da profissão. A intenção principal por detrás do decreto parece ter sido a de minar o papel exercido pelas organizações de esquerda como intermediários do processo de admissão de novos jornalistas pelas organizações noticiosas. A expectativa era de que os jornalistas oriundos da universidade teriam um perfil mais técnico do que os seus antecessores, e para garantir que isto de fato ocorreria, o regime promoveu uma ampla reforma do ensino universitário, dando origem ao atual modelo de curso em "Comunicação Social"

\footnotetext{
${ }^{22}$ A partir de 1962, o Conselho Federal de Educação passou a legislar as bases curriculares mínimas do ensino de jornalismo. Assim, os dois primeiros, o de 1962 e o de 1966 se dividiam em disciplinas da área de humanas e disciplinas técnicas, conservando a ênfase nas primeiras com o intuito de dar ao futuro profissional uma vasta cultura geral e múltiplas habilidades para trabalhar em qualquer área da comunicação. Somente a partir do currículo de 1969 é que o curso ganha a denominação de "Comunicação Social" e este uma estrutura habilitacional: Jornalismo, Relações Públicas, Publicidade e Propaganda, Editoração e Polivalente. Isto gerou uma divisão na comunidade acadêmica. De um lado, a Associação Brasileira de Ensino e Pesquisa em Comunicação, liderada pelo prof. Roberto do Amaral Vieira, acusava o currículo de privilegiar o ensino técnico e a formação específica e deixar em segundo plano a formação teórica ampla necessária para o comunicador social intervir na realidade social. De outro, um grupo de pesquisadores paulistas liderados pelo prof. José Marques de Melo acusava o currículo de tomar a comunicação como um sistema e não como um conjunto de profissões estruturalmente interligadas, mas funcionalmente diversificadas. As reformas curriculares de 1977 e 1984 marcam o avanço gradual do segundo grupo de forma articulada com outros setores, entre os quais a Associação Nacional dos Jornais, Federação Nacional dos Jornalistas e a Associação de Brasileira de Escolas de Comunicação (representante do setor privado da área de ensino). Esta articulação conseguiu impor ao Conselho a visão de que o ensino da Comunicação devia seguir os imperativos da divisão social do trabalho, consagrar a
} 
O decreto-lei teve um impacto profundo no jornalismo brasileiro. Para começar, ele estimulou uma multiplicação extraordinária dos cursos de graduação em jornalismo no país. Segundo Maria Helena Weber (2000:168) entre 1968 e 1972, o número de cursos mais do que dobrou, de 20 para 46. Isso significa que a oferta de mão de obra especializada para o trabalho no jornalismo logo se tornou muito superior ao número de postos de trabalho nas empresas jornalísticas ${ }^{23}$. Nestas circunstâncias, a admissão de novos jornalistas se tornou necessariamente um processo mais impessoal e, conseqüentemente, se tornou mais difícil para o PCB e outras organizações de esquerda usar suas redes de relacionamento para infiltrar membros e aliados nos jornais.

Devido ao seu treinamento formal em jornalismo, e contando com o apoio legal proporcionado pelo decreto-lei $n^{\circ}$ 972, os novos jornalistas eram mais propensos a desenvolver uma atitude individualista sobre o seu emprego do que seus colegas mais veteranos: eles tendiam a entendê-lo como uma conseqüência de seu mérito pessoal e formação especializada, antes que como um favor que eles deveriam retribuir $^{24}$. Isso não significa, porém, que o perfil dos novos jornalistas

separação de tarefas, enfatizar o ensino das técnicas que davam identidade a cada uma das habilitações e terminar com a idéia do comunicador polivalente para dar lugar ao especialista. Ver Melo, Fadul e Lins da Silva: 1979: 75-85, Vieira, 1978: 281 e Silva, 2007: 81-89 e 163-176. ${ }^{23}$ A saturação do mercado nas redações teve como contrapartida o deslocamento dos jornalistas para o setor de assessorias de imprensa disputado com os profissionais de relações públicas. A ocupação deste mercado nos anos 1980 se deveu ao papel exercido pelas entidades de classe dos jornalistas. O Sindicato de São Paulo realizou dois Encontros Estaduais (1983 e 1984) tentando diminuir as rivalidades entre jornalistas e assessores e regulamentar o trabalho dos últimos na chamada comunicação empresarial. O Sindicato do Rio de Janeiro realizou um Seminário Intersindical para convencer os sindicatos de outras categorias a contratar jornalistas profissionais para os seus departamentos de imprensa em detrimento do uso de militantes. Em 1986, a FENAJ, após um acordo Vera Giangrande, presidente do Conselho Federal de Relações Públicas, CONFERP, sedimentou a ocupação do mercado de assessorias e publicou o Manual de Assessoria de Imprensa no qual afirma que "os profissionais de assessoria de imprensa são antes de tudo, jornalistas" e que o trabalho dos assessores é, sobretudo, o de "agilizar e complementar o trabalho do repórter, subsidiá-lo e lhe oferecer alternativas adequadas, garantindo o fluxo de informações para os veículos de comunicação". Esse esforço de "jornalização" do setor de assessoria deu resultado. Em 1986, dos 17.500 jornalistas com carteira de trabalho assinada no Brasil, 9.600 trabalhavam no setor "extra-redação", nome que designava empresas não jornalísticas do setor público e/ou privado e englobava um leque muito diverso de instituições como as organizações não governamentais, partidos políticos, sindicatos, movimentos sociais etc. Ver, SILVA, 2007: 126-155.

24 Proença (2004, p. 153-156) chamou atenção para o paralelismo de três processos: a obrigatoriedade da formação universitária, a especialização do campo da comunicação e crescimento das assessorias de imprensa. Justamente pelo fato de se verem como 
correspondesse ao perfil "técnico" desejado pelas autoridades do regime militar. Na virada para a década de 1970, as universidades brasileiras - como de resto, as de todo o mundo - se tornaram um terreno fértil para os grupos de esquerda radical, os quais, diferentemente do $\mathrm{PCB}$, adotavam uma retórica revolucionária e, em alguns casos, se engajaram na luta armada contra o regime. Em muitos cursos, os alunos de jornalismo foram apresentados na universidade a conceitos de extração marxista, tais como Indústria Cultural e Aparelhos Ideológicos de Estado, que os estimulavam a desnaturalizar aspectos da técnica do jornalismo e contestar o discurso da neutralidade jornalística. Paradoxalmente, mesmo as disciplinas técnicas dos cursos de jornalismo contribuíam para dissociar os seus alunos do ethos profissional sonhado pelas autoridades. Afinal, os princípios e valores que os acompanhavam, inspirados no modelo americano de jornalismo, eram sistematicamente desmentidos pela prática do jornalismo no mundo real, caracterizada por toda ordem de restrições, intimidação, censura e auto-censura. Assim, muitos jornalistas passaram a ver os códigos da objetividade jornalística como um álibi para a conivência em relação ao regime ${ }^{25}$. Obviamente, nem todos os jornalistas formados tinham uma

\footnotetext{
"especialistas" em comunicação que parte dos jornalistas graduados não se subjugava a opinião de veteranos com destaque no jornalismo, como Alberto Dines, para quem jornalistas e assessores eram adversários e não pares (Silva, 2007: 100-102). Dines é um notório defensor da obrigatoriedade do diploma, porém desconsidera que foi a obrigatoriedade da formação universitária que conferiu o elo entre estas duas funções (Adghirni, 2004: 142). O papel dos sindicatos como líderes de uma cruzada corporativa ao defender a exigência do diploma e legitimar essa ampla faixa do mercado em comunicação como uma reserva de mercado para jovens jornalistas graduados (Albuquerque, 2006: 84) acabou por produzir um efeito contrário ao que aconteceu nos EUA. Enquanto lá a objetividade foi um valor fundamental para os jornalistas fundamentarem os seus critérios de noticiabilidade e distinguirem o seu ethos profissional dos assessores, no Brasil o conhecimento do que é uma informação objetiva, ao que parece, diluiu a fronteira entre esses dois agentes. Isto fica explícito fica explícito no depoimento de Nair Suzuki, chefe de reportagem da Agência Folha num debate realizado no Sindicato de Jornalistas de São Paulo em 1982: Esses jornalistas que estão deixando de ser repórteres para virarem fonte devem estar conscientes de que assessores de imprensa de governo são profissionais e como tais, acredito que contribuirão para dar um tratamento mais adequado à notícia, informando corretamente a opinião pública (Silva: 2007: 125).

25 Um fenômeno bastante complexo, o chamado "jornalismo alternativo" foi em boa medida estimulado pela crença de que o verdadeiro jornalismo não podia ser exercido no âmbito da grande imprensa. Conforme Kucinski (1991: XXIII-XXIV), isto ocorria porque os jornais alternativos tinham uma cultura jornalística marcada pelo relativo desprendimento salarial, no qual o trabalho era até então compensado por satisfações literárias, intelectuais e ideológicas. Isto diferia da grande empresa jornalística, lugar em que o jornalista teria de abdicar de ser o sujeito consciente de suas ações, abrir mão de sua autonomia intelectual e
} 
perspectiva individualista sobre sua profissão e, entre eles, havia membros e simpatizantes do PCB. Contudo, a absorção de um número crescente de jornalistas com uma formação diferenciada dos demais se provou um fator de tensão nas salas de redação. Cláudio Abramo (1988), por exemplo, retrata os jornalistas formados como egoístas, arrogantes e imprudentes.

Por essa época, os jornais estavam modernizando a sua infra-estrutura e se tornando organizações mais complexas. As sedes dos jornais se tornaram maiores, o número de jornalistas aumentou e os laços entre eles se tornaram mais impessoais e burocráticos (Corrêa, 2002). Em tais circunstâncias, o velho esquema disciplinar e as redes de solidariedade de que se servia o PCB encontravam um terreno muito menos fértil para florescer. No final da década de 1970, sob a influência do movimento do Novo Sindicalismo - que deu origem ao Partido dos Trabalhadores (PT) - muitos jornalistas passaram a se identificar menos como intelectuais do que como membros da classe trabalhadora, cujos interesses eram diametralmente opostos aos dos patrões $^{26}$.

Em 1977/78 o Sindicato dos Jornalistas Profissionais do Estado de São Paulo propôs a criação do Conselho Consultivo dos Representantes de Redação (CCRR), descrito por Perseu Abramo como "um órgão de pressão dos jornalistas contra os patrões, e, por tabela, contra o sistema" (1997: 289). Provavelmente inspirado pelo

política para se subornar ao arbítrio imposto pelas relações de trabalho tipicamente assalariadas.

${ }^{26} \mathrm{O}$ modelo de ação dos novos sindicalistas estava centrado nas seguintes premissas: origem e centro no setor moderno da economia, autonomia diante dos partidos e do Estado, organização voltada para a base e ímpeto reivindicativo direcionado para os interesses dos trabalhadores. No caso dos jornalistas, este modelo de ação foi firmado por lideranças que se opunham a política aliancista do PCB por priorizar a luta institucional pela retomado pelo Estado de Direito, deixando em segundo plano a luta dos trabalhadores pela conquista de direitos sociais (Santana, 1999:137). A estratégia dos novos sindicalistas de levar a luta de classe para o primeiro plano das lutas políticas pode ter encontrado ressonância em boa parte da mão de obra jornalística que compunha o escalão inferior das empresas, entre os quais repórteres anônimos, diagramadores, fotógrafos etc. Smith (1997: 53-57) mostrou que desde meados dos anos 1970 este grupo estava mais atormentado por questões materiais, relativas à precariedade salarial e a rotatividade no emprego do que por questões relacionadas à censura. Assim, muitos se beneficiavam da jornada de cinco horas para buscar outro emprego e, com isso, eles acabavam exercendo a função de jornalista paralelamente a de assessor ou relações públicas no setor público ou privado. Eles se consideravam, no geral, empregados ou trabalhadores comuns. Portanto, eles estavam não só abertos a uma retórica corporativista pautada pela regulação do mercado de trabalho, mas a outra, de viés classista. Esta veio a público quando lideranças identificadas com o novo sindicalismo tomaram a direção de um dos principais sindicatos de jornalistas do país, o de São Paulo (Silva, 2007: 179). 
exemplo do Portugal pós-revolucionário (Agee e Traquina, s.d.), o sindicato paulista passou a reivindicar que o CCRR deveria desempenhar um papel ativo no processo de produção das notícias, a fim de garantir uma maior diversidade de perspectivas no enfoque ideológico contido no material noticioso ${ }^{27}$.

Em 1979, o Sindicato dos Jornalistas de São Paulo liderou uma greve, cuja pauta incluía a reivindicação de aumento salarial para a categoria e o reconhecimento do CCRR pelos donos de jornais. Não obstante um grande número de jornalistas tenha entrado em greve, a adesão não bastou para interromper a circulação dos jornais ${ }^{28}$. Muitos jornalistas que eram membros do PCB foram contrários ao movimento grevista, e alguns tentaram exercer um papel conciliatório, mediando a relação entre os donos de jornal e os jornalistas em greve ${ }^{29}$. Contudo, o PCB já não

27 O CCRR era uma reunião plenária formada pelos representantes escolhidos pelos jornalistas nas redações através de eleições diretas e secretas. Ele era coordenado por três membros eleitos entre os representantes que deveriam trabalhar em contato permanente com a direção do SJPSP. De acordo com o Perseu Abramo (1997: 288-290), o CCRR era um organismo cujas potencialidades para dinamizar a vida sindical eram imensas, tendo em vista a dupla inserção dos jornalistas na sociedade: como trabalhadores assalariados em empresas jornalísticas e como potenciais porta-vozes das demandas gerais dos grupos sociais. Isso dizia respeito à questão da liberdade de imprensa afetada naquele contexto pelas restrições organizacionais das empresas que impediam os jornalistas de exercerem autonomamente o seu trabalho. Neste sentido, o CCRR foi concebido não só para ativar a luta de classes, mas como uma instância com o potencial para reconfigurar as relações de trabalho e de poder nas redações. Isto fez com que alguns jornais, como $O$ Estado de $S$. Paulo, acusassem este organismo de ser um soviete (Silva: Ibid:181)

${ }^{28}$ A greve ocorreu em maio de 1979 e os jornalistas foram derrotados em função do Tribunal Regional do Trabalho decretar a ilegalidade da greve a pedido das empresas. Mas o importante é compreender o peso que as reformas estruturais operadas nas empresas jornalísticas tiveram na derrota do movimento. Fausto Cupertino e Fúlvio Abramo, respectivamente diretor do Diário do Comércio e repórter da Gazeta Mercantil em São Paulo, apontaram para o fato dos jornais virarem grandes empresas e os jornalistas por não terem conhecimento tecnológico deixaram de dominar todas as fases do processo de produção de notícias se tornando mão de obra descartável. José Salomão Amorim, professor da Universidade de Brasília ressaltou que a greve fracassou pelo fato dos jornais paulistas receberem material noticioso de jornais de outros estados. Isto era um indicador da existência de um novo ambiente jornalístico, centralizado pelas agências de notícias e dominado por uma estrutura sofisticada de comunicações no país, fatores que alteraram a "regra do jogo" no interior dos jornais (Ibid: 2007:191). Esses diagnósticos convergem com o de Cláudio Abramo (1993:91-92), para quem os jornalistas não tinham um conhecimento técnico e eletrônico necessário para bloquear a produção dos jornais. Alberto Dines (2003:126) afirmou que os grevistas não estavam atentos às modificações ocorridas no trabalho jornalístico por conta da tecnologia.

29 Para Alberto Dines (Ibidem), a greve foi fruto da ação de um grupo radical, que depois se incorporou ao PT. Em oposição aos radicais estavam os quadros intermediários, os comandos dos jornais e do pessoal do $\mathrm{PCB}$, definidos por ele como as pessoas politicamente mais preparadas. Cláudio Abramo, Mino Carta, Milton Coelho da Graça e Roberto Muller foram os 
tinha mais a influência de antes e perdia aceleradamente a sua condição de principal referencial da esquerda para o recém-nascido PT, que tinha uma atitude muito mais combativa com relação ao empresariado.

Os donos de jornais tomaram a greve como uma traição e uma séria ameaça contra os seus interesses, e retaliaram duramente, demitindo um grande número de jornalistas. Dado que o PCB não era mais necessário para prover jornalistas preparados para as organizações noticiosas, e visto que sua influência sobre os jornalistas havia decrescido de tal modo que não era mais suficiente para garantir a disciplina e as redes de lealdade nas salas de redação, os donos dos jornais acharam que já era a hora de assumir um controle mais direto sobre ela.

A reforma do jornal Folha de S. Paulo oferece o exemplo mais dramático disto: o "Projeto Folha" visava redefinir totalmente a cultura profissional do jornal. Para tal, a Folha de S. Paulo publicou um manual de redação que enfatizava o compromisso dos jornalistas com o valor da objetividade e dava instruções bastante detalhadas sobre o modo como os jornalistas deveriam se comportar no processo de produção das notícias (cabe destacar que a cobertura da greve mereceu um tópico especial e bastante detalhado por parte do manual). Ainda mais importante, o manual enfatizava que os jornalistas deveriam se dedicar inteiramente à Folha de $\mathrm{S}$. Paulo - e através dele, com o "leitorado", ou seja, os leitores que, ao comprarem o jornal, emprestavam a ele legitimidade para falar em seu nome - e que tal compromisso não poderia ser dividido com nenhum partido político ${ }^{30}$.

que tentaram intermediar uma solução negociada entre o Sindicato, porém fracassaram e foram acusados de serem divisionistas (Abramo, 1993: 92 e Silva, 2003: 260) $3^{0}$ Segundo Otávio Frias Filho (2003, p. 359-360) um dos motivos principais da implantação do Projeto Folha foi a retomada do controle da redação pela empresa: Era um clima muito difícil. Era comum eu tomar uma decisão e a redação parar. Então vinha uma comissão que vinha discutir por que tal decisão foi tomada, por que não sei o quê. Havia, na gestão do Boris Casoy (1979-1982), um clima de grande mobilização, possibilidade de expressão e as pessoas achavam que o próximo passo era a autogestão. Paradoxalmente, uma das conseqüências geradas neste processo foi a ascensão de jovens militantes sindicais e/ou de correntes políticas de esquerda (Caio Túlio Costa, Paulo Nogueira, da Ag. Folhas, Mário Sérgio Conti e Sheila Carvalho entre outros) na carreira e às estruturas de poder de jornal, até então em mãos dos chefes de redação carismáticos, como Cláudio Abramo (Silva, 2007: 195). A outra foi o uso normativo da objetividade por parte das empresas objetividade tendo em vista o interesse das mesmas em conter e disciplinar o caráter abertamente ideológico da produção jornalística. Isto permitiu os jornais vincularem a lealdade do leitor não somente na linha editorial, mas em parâmetros jornalísticos e administrativos que julgavam capazes de 


\title{
Conclusão
}

Em seu livro A síndrome da antena parabólica, Bernardo Kucinski lamenta que a auto-censura é uma atitude largamente difundida entre os jornalistas brasileiros atuais. Segundo ele, a longa prática da auto-censura durante os anos do regime militar gerou uma cultura jornalística perversa:

\begin{abstract}
“ [...] um dos traços que mais distingue o jornalismo brasileiro do jornalismo de culturas de maior tradição democrática é a sua relativização do valor verdade na ética profissional. Enquanto na escala de valores da ética do jornalismo liberal dos países pósindustriais o valor verdade ocupa uma posição central, no jornalismo brasileiro este valor é deslocado para o valor responsabilidade e outros valores, tais como lealdades pessoais do repórter e/ou a lealdade da empresa jornalística ao poder ou a interesses particulares, ou mesmo pelo valor sucesso pessoal" (1998: 69)
\end{abstract}

Ainda que concordemos com o diagnóstico de Kucinski sobre os problemas do jornalismo brasileiro atual, acreditamos que as raízes do problema são mais profundas e complexas do que o autor sugere. Acreditamos que auto-censura sistemática passou a ser exercida pelos jornalistas antes do regime militar, e não pode ser entendida como uma mera conseqüência da repressão política. Ela foi o preço que os jornalistas aceitaram pagar para exercer alguma influência nas salas de redação dos jornais conservadores. Esta análise vai ao encontro de observações feitas pelo próprio Kucinski, que destaca a influência comunista nas redações no período anterior ao regime militar, e afirma que a "clandestinidade intelectual, derivada e companheira da clandestinidade política, já era parte do éthos do jornalista com carteirinha de esquerda mesmo antes do golpe" (1998: 68). Discordamos, contudo, da sua sugestão de que "para esses quadros jornalísticos, altamente conscientes, esclarecidos e politizados, a militância se dava fora da redação” (1998: 68).

Defendemos, neste artigo, que a presença de muitos comunistas entre os jornalistas, entre as décadas de 1950 e 1970, não aconteceu a despeito da sua posição política, mas em boa medida, por causa dela. Entre esses jornalistas e os donos dos

controlar como a "eficácia da cobertura", os "custos de assinatura" e os "serviços de distribuição". Isto explica a afirmação de Carlos Eduardo Lins da Silva de que a lógica da objetividade para os condutores do Projeto Folha não era ética nem política, mas mercadológica. Ver Soloski, 1993: 96-97 e Lins da Silva, 2005: 130. 
jornais se estabeleceu uma relação simbiótica. Estes toleravam a presença maciça de comunistas nos seus jornais não porque gostassem deles, mas porque eles precisavam de jornalistas preparados, disciplinados e leais para apoiar seu projeto de modernização dos jornais, e o PCB podia oferecê-los para eles, em troca de exercer alguma influência nas salas de redação. Esta surpreendente aliança desempenhou um papel muito importante para tornar possível a adaptação do modelo liberal de jornalismo, para o Brazil, em condições muito diferentes das que ele encontrou para se desenvolver, nos Estados Unidos. Não é de surpreender que a forma adaptada resultou em algo muito diferente do modelo original. Como conclusão, sugerimos que a análise do desenvolvimento do jornalismo em países periféricos deve enfocar o processo dinâmico de re-leitura e adaptação dos modelos dos países centrais, antes que classificá-los com base em modelos que, de algum modo, são "estáticos".

\section{Referências Bibliográficas}

Abramo, Cláudio (1993). A regra do jogo. São Paulo: Companhia das Letras.

Abramo, Perseu (1997). Um trabalhador da notícia. Textos de Perseu Abramo. São Paulo: Editora Fundação Perseu Abramo.

Abreu, Alzira Alves de (2003). Jornalistas e jornalismo econômico na transição democrática. In Alzira Alves de Abreu et al. Mídia e Política no Brasil: Jornalismo e Ficção. Rio de Janeiro: FGV Editora.

Adghirni, Zélia Leal (2004). Hibridação e Gêneros Midiáticos: A Informação Jornalística Pelas Instituições de Comunicação. Ícone. Programa de PósGraduação UFPE/7: 140-152.

Agee, Warren K. \& Nelson Traquina (s.d). O quarto poder frustrado. Os meios de comunicação social no Portugal pós-revolucionário. Lisboa: Vega.

Albuquerque, Afonso de (2005). Another 'Fourth Branch'. Press and political culture in Brazil. Journalism 6 (4): 489-507. (2006) A Obrigatoriedade do Diploma e a Identidade Jornalística: Um Olhar pelas Margens. Contracampo. Programa de Pós-Graduação UFF/14: 73-90.

Almeida, Maria Hermínia Tavares de \& Luiz Weis (1998). Carro-Zero e Pau de Arara: o cotidiano da oposição de classe média ao regime militar. In Fernando Novais \& Lilia Moritz Schwarcz. A História da Vida Privada. Volume 4. São Paulo: Companhia da Letras.

Amaral, Luiz (1996). A objetividade jornalística. Porto Alegre: Sagra-D.C.Luzatto. 
Andrade, Evandro Carlos de (2003). Depoimento a Fernando Lattman-Weltman. In Alzira Alves de Abreu et alii. Eles mudaram a imprensa: depoimentos ao CPDOC. Rio de Janeiro: FGV Editora, p. 14-67.

Bahia, Juarez (1990). Jornal, história e técnica. São Paulo, Editora Ática.

Blanchard, Margaret A. (1986). Exporting the First Amendment. The PressGovernment Crusade of 1945-1952. New York: Longman.

Chalaby, Jean K. (1996) Journalism as an Anglo-American Invention: A Comparison of the Development of French and Anglo-American Journalism, 1830s-1920s. European Journal of Communication, vol. 11 (3) p. 303-326.

Conti, Mario Sergio (1999). Notícias do Planalto: a Imprensa e Fernando Collor. São Paulo: Companhia das Letras.

Corrêa, Villas-Bôas (2002). Conversa com a Memória. A história de meio século de jornalismo político. Rio de Janeiro: Objetiva.

Costa, Caio Túlio (1991). O relógio de Pascal. A experiência do primeiro ombudsman da imprensa brasileira. São Paulo: Siciliano.

Dines, Alberto (2003). Entrevista em Alzira Alves de Abreu, Fernando LattmanWeltman \& Dora Rocha. Eles Mudaram a Imprensa. Rio de Janeiro: Editora FGV.

Ferreira, Jorge (2002). Prisioneiros do Mito. Cultura e Imaginário Político dos Comunistas no Brasil (1930-1956). Rio de Janeiro, Mauad-Eduff.

Frederico, Celso (1998). “A Política Cultural dos Comunistas”. In João Quartin de Moraes (org) História do Marxismo no Brasil. V. III.. Campinas, Unicamp, 1998.

Frias Filho, Otávio (2003). Entrevista em Alzira Alves de Abreu, Fernando LattmanWeltman \& Dora Rocha. Eles Mudaram a Imprensa. Rio de Janeiro: Editora FGV.

Hallin, Daniel C. \& Mancini, Paolo (1984). "Speaking of the President: Political Structure and Representational Form in U.S. and Italian television news". Theory and Society, 13, p. 829-850.

Hallin, Daniel C. \& Paolo Mancini (2004) Comparing Media Systems: Three Models of Media and Politics. Cambridge: Cambridge University Press.

Köcher, Renate (1986). Bloodhounds or Missionaries: Role Definitions of German and British Journalists. European Journal of Communication 1 (1): 43-64

Kucinski, Bernardo (1998). A síndrome da antena parabólica. Ética no jornalismo brasileiro. São Paulo: Editora Fundação Perseu Abramo.

.Jornalistas e revolucionários nos tempos da imprensa Alternativa. São Paulo: Scritta, 1991.

Lins da Silva, Carlos Eduardo (2005). Mil dias: Seis Mil Dias Depois. São Paulo: PubliFolha.

Markun, Paulo (2005). Meu querido Vlado. Rio de Janeiro: Objetiva. 
Mauss, Marcel (sem data). Ensaio sobre a dádiva. Lisboa: Edições 70.

Mayrink, José Maria (2002). Vida de repórter. São Paulo: Geração Editorial.

Melo, José Marques de Melo, FADUL, Anamaria, Lins da SILVA, Carlos Eduardo. Ideologia e Poder no Ensino da Comunicação. São Paulo, Cortez \& Moraes Intercom, 1979.

Moraes, Dênis de (1994). O Imaginário Vigiado. A Imprensa Comunista e o Realismo Socialista no Brasil. Rio de Janeiro: José Olympio.

Moraes, Mário Sérgio de (2006). O Ocaso da Ditadura: Caso Herzog. São Paulo, Barcarolla.

Muller Filho, Roberto. (2003). Entrevista em Alzira Alves de Abreu, Fernando Lattman-Weltman \& Dora Rocha. Eles Mudaram a Imprensa. Rio de Janeiro: Editora FGV.

Pandolfi, Dulce (1995). Camaradas e companheiros: História e Memória do PCB. Rio de Janeiro, Relume Dumará.

Proença, José Luiz (2004). Do assédio implícito ao jornal prateleira. In Boanerges Lopes \& Roberto Fonseca Vieira (orgs). Jornalismo e Relações Públicas: Ação e Reação. Rio de Janeiro, Mauad.

Ribeiro, Ana Paula Goulart (2001). Clientelismo, corrupção e publicidade: como sobrevivem as empresas jornalísticas no Rio de Janeiro dos anos 50? In Marialva Barbosa (org). Estudos de Jornalismo I. Niterói: Ed. do Mestrado em Comunicação, Imagem e Informação/INTERCOM, P. 42-55.

Rossi, Clovis (1980). O que é jornalismo. São Paulo, Brasiliense.

Siebert, Fred S.; Theodore Peterson \& Wilbur Schramm (1963/1956). Four Theories of the Press. Urbana and Chicago: University of Illinois Press.

Silva, Marco Antônio Roxo da (2003). Companheiros em Luta: A greve dos Jornalistas de 1979. Dissertação de Mestrado. Niterói, PPGCOM/UFF.

(2007). Jornalistas, Pra Quê? Militância Sindical e o Drama da Identidade Profissional. Tese de Doutorado. Niterói, PPGCOM/UFF.

Smith, Anne-Marie (2000). Um acordo forçado. O consentimento da imprensa à censura no Brasil. Rio de Janeiro: Editora FGV.

Soloski, John (1993). "O Jornalismo e o Profissionalismo: Alguns Constrangimentos no Trabalho Jornalístico”. In: Nelson Traquina. Jornalismo: questões, teorias e "estórias". Lisboa, Vega.

Waisbord, Silvio (2000). Watchdog Journalism in South America: News, Accountability, and Democracy. New York: Columbia University Press.

Vieira, Roberto Amaral (1978). A Formação Básica de Um Comunicador Voltada para a Realidade Brasileira. In: Roberto Amaral Vieira (org). Comunicação de Massa: O Impasse Brasileiro. Rio de Janeiro: Forense-Universitária. 